\title{
Achievements in the utilization of poplar wood - guideposts for the future ${ }^{1}$
}

\author{
by John J. Balatinecz ${ }^{2}$, David E. Kretschmann ${ }^{3}$ and André Leclercq ${ }^{4}$
}

From an early status as a "weed tree," poplar has become an important commercial genus in North America during the past 20 years. The many and varied uses of poplar wood now include pulp and paper, lumber, veneer, plywood, composite panels, structural composite lumber, containers, pallets, furniture components, match splints and chopsticks. The high cellulose and relatively low lignin content make poplars well suited for pulp and paper products. The wood can be pulped by all commercial pulping methods, such as mechanical, semi-chemical, sulphate and sulphite processes. Poplar pulps are utilized in fine papers, tissues, paperboard, newsprint and packaging papers. Poplar kraft pulps, when blended with softwood kraft, are particularly well suited for fine paper manufacture because of inherently desirable properties, such as excellent sheet formation, high opacity, good bulk and good printability. While poplar wood continues to be an important raw material in the traditional lumber, veneer and plywood industries, the most remarkable recent achievement in poplar utilization is the phenomenal growth of the oriented strandboard and structural composite lumber industries in North America during the last decade. The future for poplar utilization is bright. On the resource production side, opportunities for genetically modifying important wood properties, such as chemical composition, fibre quality and natural durability of wood, can now be realized. On the resource utilization side, high-value engineered composites and high-yield pulp and paper products will represent the strongest growth sectors for poplar fibre during the coming decades.

Key words: poplar wood, utilization, pulp and paper, oriented strandboard, fibre properties

À l'origine, une espèce « indésirable », le peuplier est devenu un genre important en terme commercial en Amérique du Nord au cours des dernières 20 années. Les usages multiples et variés du bois de peuplier comprennent maintenant la pâte et le papier, le bois d'œuvre, le déroulage, le contre-plaqué, les panneaux composites, le bois d'ingénierie pour les charpentes, les conteneurs, les palettes, les composantes de meuble, les allumettes et les baguettes. Le fort contenu en cellulose et la relativement faible portion de lignine font en sorte que les peupliers sont recherchés pour la production de pâte et de papier. Le bois peut être transformés en pâte selon tous les procédés commerciaux de mis en pâte qu'il soit mécanique, semi-chimique, au sulfate ou au sulfite. Les pâtes de peuplier sont utilisées dans les papiers fins, les papiers hygiéniques, les cartons, le papier journal et les papiers d'emballage. Les pâtes kraft de peuplier, lorsque mélangées à de la pâte kraft de résineux, sont particulièrement intéressantes pour la fabrication de papier fin par suite des propriétés inhérentes recherchées, comme l'excellente formation de feuille de papier, la grande opacité, une masse adéquate et une bonne qualité typographique. Même si le bois de peuplier continue d'être une importante source de matière brute pour le bois d'œuvre traditionnel, le déroulage et le contre-plaqué, la plus remarquable réalisation récente dans l'utilisation du peuplier réside dans la croissance phénoménale des industries de panneaux à lamelles orientées et dans le bois d'ingénierie pour les charpentes en Amérique du Nord au cours de la dernière décennie. L'avenir de l'utilisation du peuplier est intéressant. Du côté de la production de la ressource, les possibilités entourant la modification par voie génétique des principales propriétés du bois, telle la composition chimique, la qualité des fibres et la durabilité naturelle du bois, peuvent être maintenant mises en fonction. Du côté de l'utilisation de la ressource, les composantes d'ingénierie à grande valeur et les produits de pâte et de papier à haut rendement constitueront les secteurs de croissance les plus importants pour la fibre de peuplier au cours des prochaines décennies.

Mots-clés : bois de peuplier, utilisation, pâte et papier, panneaux de lamelles orientées, propriétés des fibres

\section{Introduction}

To satisfy the increasing demand for forest products, fast-growing trees such as poplar grown in managed plantations are being seriously considered for future supply needs. This review paper discusses the properties of poplar that make it appealing for a number of different utilization options and the characteristics that cause it to have some

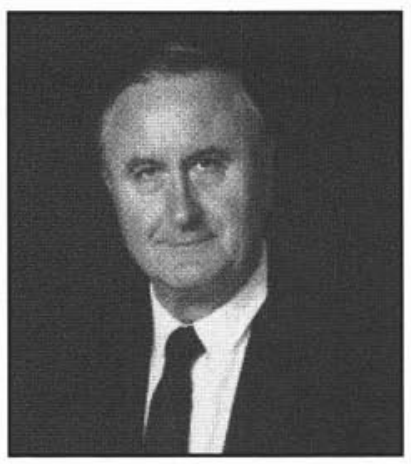

John J. Balatinecz

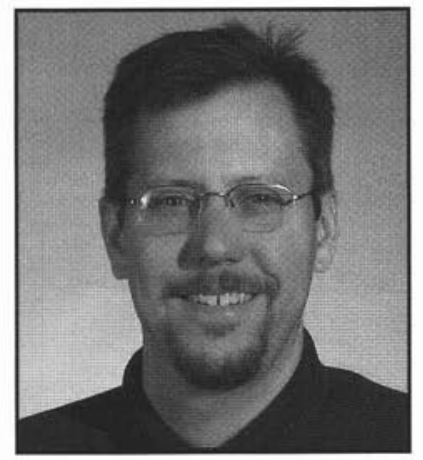

David E. Kretschmann

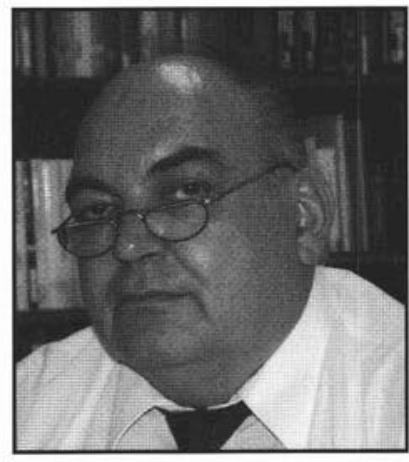

André Leclercq
${ }^{1}$ Presented at the 21st Session of the International Poplar Commission, September 24-28, 2000, Vancouver, Washington, USA.

${ }^{2}$ Faculty of Forestry, University of Toronto, Toronto, ON M5S 3B3.

${ }^{3}$ USDA, Forest Service, Forest Products Laboratory, Madison, WI, USA 537052398.

${ }^{4}$ Centre de Recherche de la Nature, des Forêts et du Bois, B-5030 Gembloux, Belgium. unique drawbacks. The information presented is primarily based on the North American experience with utilization of poplar wood from natural forests as well as with research on fast-growing poplar hybrids. Since there is an intimate relationship between basic wood characteristics and product suitability, the properties of poplar wood will be discussed first. 
The genus Populus includes trees that are commonly called "poplar." The genus has a very wide distribution in North America, with various species inhabiting a triangular region stretching from Louisiana to Newfoundland to Alaska. The best known species of Populus include trembling aspen (P. tremuloides), bigtooth aspen ( $P$. grandidentata), balsam poplar ( $P$. balsamifera), eastern cottonwood ( $P$. deltoides), and black cottonwood $(P$. trichocarpa). All of these species can be characterized as fastgrowing, moisture-loving, and shade-intolerant, medium to large trees with a short life span. The most frequently used and widely distributed commercial species are trembling aspen and bigtooth aspen.

In the past, poplar trees were regarded as weed trees that needed to be removed from timber stands. Most harvested aspen was used for pulp, lumber, hardboard, and insulation board. With the introduction of waferboard and oriented strandboard (OSB), aspen utilization exploded, increasing threefold from 1975 to 1989 (Youngquist and Spelter 1990), with a utilization level today almost four times greater than in 1975. The utilization level has increased so much that there is a concern that the aspen cut will exceed growth and the aspen supply will not be adequate to support the growing solid wood, composite, and paper industries in the Lake States region of the U.S. Similar concern has been expressed in Canada across the aspen belt, from British Columbia to the Maritimes (Morley and Balatinecz 1993),

\section{Properties}

The wood of all poplar species has relatively low density and diffuse porous structure. The average relative density (i.e., specific gravity) of species grown in natural forests in North America, as well as of hybrid poplars, is in the range of 0.30 to 0.39 . The strength properties of poplars are relatively low. However, in bending strength and stiffness they compare favourably with common construction species such as spruce, pine, and fir. Considerable variation exists in properties between different geographic locations (e.g., note the differences for trembling aspen and balsam poplar from natural stands in Canada and the U.S., Table 1). Standing poplar trees have high moisture content, typically about $100 \%$, with only minor differences between sapwood and heartwood. Seasonal fluctuations exist, with summer values being somewhat lower than winter values. These high moisture levels make the wood suitable for cutting strands or wafers without steaming. Considering their low density, poplar species have high volumetric shrinkage (11\% to $12 \%$ ). Poplars also have a high ratio of tangential to radial shrinkage, which is the main cause of form defects during drying (such as cupping and diamonding).

The volumetric composition of poplar wood is dominated by the relatively high proportion of fibres ( $53 \%$ to $60 \%$ ), followed by vessel elements ( $28 \%$ to $34 \%)$, ray cells $(11 \%$ to $14 \%)$, and a negligible proportion of axial parenchyma ( $0.1 \%$ to $0.3 \%)$ (Panshin and de Zeeuw 1980). The relative density of wood is most strongly influenced by the vessel-to-fibre ratio, as well as the diameter and wall thickness of fibres and vessel elements. Notably, the aspens, which have slightly higher relative density than the cottonwoods, are characterized by vessels with smaller diameters and fibres with slightly thicker walls. Fibre length increases with age and position in the tree in both hybrid and indigenous poplars (Fig.1, Koubaa et al. 1998).

The average length of vessel elements in mature poplar wood is in the range of 0.58 to $0.67 \mathrm{~mm}$, whereas average fibre length ranges from 1.3 to $1.4 \mathrm{~mm}$ (Panshin and de Zeeuw 1980). The "paper-making fibres" (that is, tracheids) of softwoods are considerably longer ( 3 to $4 \mathrm{~mm}$ long). These fundamental differences in fibre length explain why softwood pulps have better properties, especially in tear, burst, and breaking length. On the other hand, the vessel elements of poplar significantly enhance the smoothness and opacity of sheets, making poplars well suited for printing papers.

The chemical composition of poplar wood is characterized by high polysaccharide content (approximately $80 \%$ holocellulose, made up of $50 \%$ cellulose and $30 \%$ hemicelluloses) and low lignin content (about $20 \%$ or less). Consequently, sulphate pulp yields are in the range of $52 \%$ to $56 \%$, which is considerably higher than the $44 \%$ to $46 \%$ yields achieved for most softwoods. The extractives content of poplar toxic to fungi is low, which makes the wood susceptible to decay.

Poplars also possess a number of characteristics that present challenges to utilization. Poplars in general are known to have stems with wet wood pockets, which makes uniform drying difficult. Poplar stems are susceptible to discoloration and decay. Discoloured and decayed wood can be a major defect that limits the value of wood for most end uses, especially for cabinetry and mouldings. Research by Eckstein et al. (1979) suggests that the compartmentalizing capacity (the ability of a stem to restrict spread of discoloration or decay) of hybrid poplar trees is under genetic control. They suggested that selecting clones based on conducting tissue may be an effective strategy for breeding trees for use in secondary lumber manufacture where colour is important (e.g., millwork and cabinets).

Poplars develop tension wood quite readily (Isebrands and Parham 1974, Holt and Murphey 1978). Tension wood is reaction wood that is formed on the upper sides of branches and the upper, usually concave, side of leaning or crooked stems. It is characterized anatomically by the lack of cell wall lignification and often by the presence of a gelatinous layer in the fibres. Tension wood is also higher than normal in cellulose and ash content but lower in lignin and hemicellulose.

The machining, bonding, and finishing properties of poplars are quite good, making the wood well suited for a variety of conversion technologies, from sawing to veneer peeling and flaking. The relative density of a wood species determines the ideal peeling and flaking temperatures. For poplars, because of their low density, the projected "ideal" peeling and flaking temperature is in the range of $16^{\circ}$ to $20^{\circ} \mathrm{C}$, but acceptable results can be achieved between $7^{\circ} \mathrm{C}$ and $30^{\circ} \mathrm{C}$. Consequently, poplar requires little or no preconditioning, because of both low density and high green moisture content. The low wood density is also an advantage in bonding of flakes and particles during the manufacture of composite panels because moderate pressure will bring the individual flakes and particles into intimate contact, thus ensuring a medium-density board with good strength. The pores in poplar wood are generally small enough to allow surface finishing without filler treatment.

\section{Utilization options}

Poplar wood is used for the manufacture of a large number and variety of primary and secondary forest products in North America, Europe and elsewhere in the world. These products include pulp and paper, lumber, veneer and plywood, composite panels, structural composite lumber, pallets, furniture components, fruit baskets, containers, match splints and 
Table 1. Average specific gravity and flexural properties of indigenous North American poplar species, a hybrid poplar (Wisconsin-5), and a few selected softwoods ${ }^{1}$.

\begin{tabular}{|c|c|c|c|c|}
\hline \multicolumn{2}{|l|}{ Species } & \multirow{2}{*}{$\begin{array}{c}\text { Specific gravity } \\
0.35\end{array}$} & \multirow{2}{*}{$\frac{\text { Modulus of rupture (MPa) }}{35.0}$} & \multirow{2}{*}{$\begin{array}{c}\text { Modulus of elasticity (GPa) } \\
5.9\end{array}$} \\
\hline Aspen, & Trembling (US) & & & \\
\hline & Trembling (Canada) & 0.37 & 38.0 & 9.0 \\
\hline & Bigtooth (US) & 0.36 & 37.0 & 7.7 \\
\hline \multirow[t]{2}{*}{ Cottonwood, } & Eastern (US) & 0.37 & 37.0 & 7.0 \\
\hline & Black (US) & 0.31 & 34.0 & 7.4 \\
\hline \multicolumn{2}{|c|}{ Balsam poplar (US) } & 0.31 & 27.0 & 5.2 \\
\hline \multicolumn{2}{|c|}{ Balsam poplar (Canada) } & 0.37 & 34.0 & 7.9 \\
\hline \multicolumn{2}{|c|}{ Hybrid poplar (Wisconsin-5) } & 0.36 & 32.2 & 7.1 \\
\hline \multicolumn{2}{|c|}{ Black spruce } & 0.38 & 42.0 & 9.5 \\
\hline \multicolumn{2}{|l|}{ Jack pine } & 0.40 & 41.0 & 7.4 \\
\hline \multicolumn{2}{|l|}{ Balsam fir } & 0.33 & 38.0 & 8.6 \\
\hline
\end{tabular}

${ }^{1}$ The properties are for green wood. Source: Forest Products Laboratory (1999).

్ㅐㅇopsticks. The wood-using industries have turned more to indigeNinous poplar resources, both in the United States and Canada, Gluring the past thirty years because of the rapidly escalating Fosts of softwood fibre and the broad availability of poplars gat a much lower cost. The same utilization possibilities exist for hybrid poplars. Hybrid poplars will have the added advantage that they can be produced closer to user industries and marQkets and perhaps be genetically engineered with quality traits for specific products. Hybrid poplars have the potential to be a major source of wood fibre in the next century (Boerjan 2000, Фిinus 2000).

JOne of the major uses of the indigenous poplar resource is कs pulp and paper products. Poplar wood can be pulped by all femmercial pulping methods. Mechanical, semi-chemical, స్ft (or sulphate), and sulphite processes are now being used. क्ञ Doplar. The major uses of poplar pulp fall into three categories: IIspecialty paper products, such as napkins, tissues, towels, fine paper, paper board for packaging, and roofing felt; building boards, such as insulation board, ceiling tiles, and hardboard;

general purpose pulp, including groundwood, kraft, semichemical, and bleached sulphite.

Poplar kraft pulps are particularly well suited to fine paper ఫुnanufacture because of inherently desirable properties such as excellent sheet formation, high opacity, good bulk, and good 矛rintability. Poplar kraft pulps can, however, have large amounts of fines and debris. Poplar kraft pulps are not made lirectly into paper; rather they are first blended with long-fibred Softwood pulp to facilitate the development of wet web strength on fast-running paper machines. Poplar sulphite pulps (mainly from aspen) have been produced in North America for nearly 40 years. These pulps are used mainly in admixtures with bleached softwood kraft for the manufacture of high-quality printing and writing papers. Relatively recent technical advances in anthraquinone-catalyzed sulphite pulping are helping to increase pulp yield and strength properties of paper (Wong 1987).

The suitability of different poplar clones for papermaking has been investigated by Labosky et al. (1983) and Law and Rioux (1997). Their work suggests that, in general, hybrid poplars have a high proportion of very short cells $(<0.2 \mathrm{~mm})$ and high lignin content compared with trembling aspen. The chemither- momechanical pulps that were produced from this material were of acceptable quality but may require more energy for refining than aspen. Growth rate of short-rotation poplar can be increased without concern that fibre length may be negatively affected (DeBell et al. 1998). Research by Zarges and Neuman (1980) indicated that selected hybrid poplars have kraft pulp properties similar to those of native poplar.

\section{Lumber}

Sawmills in the aspen belt of Canada and the United States have been manufacturing poplar lumber for the past several decades. Production volumes, however, remained quite low mainly because of economic factors. Due to small log diameters and the high incidence of decay, the average cost of sawing aspen is generally higher than for other hardwoods and is much higher than for softwoods. Markets for poplar lumber, while diverse, are also limited by strength properties and grade. The huge residential construction market in North America has always been dominated by softwood. Visually stress-graded poplar dimension lumber (including native aspens, cottonwoods, and balsam poplar) is acceptable for framing applications. It is classified under the Northern Species group in Canada and as cottonwood or aspen in the United States and has lower allowable design stresses than the predominant S-P-F (Spruce-Pine-Fir) species group, thus putting poplar at a disadvantage (Table 1). Non-stress-graded poplar lumber is used in a broad range of applications and products (pallets, crates, boxes, hidden furniture components, and lumber-core panels).

Hall et al. (1982), Hernandez et al. (1998), and Kretschmann et al. (1999) investigated the use of hybrid poplar for lumber. Hybrid poplar clones have mechanical properties similar to native cottonwood but slightly lower than those of aspen. Poplar clones have been shown to have a distinctive juvenile wood period. Strength-related properties increase with distance from the core. Therefore, the longer a poplar stand is allowed to mature, the more high-strength material will be available (Bendtsen $\mathrm{et}$ al . 1981). There is a weak but significant negative correlation between growth rate and density, and mechanical properties at breast height. Significant differences in mechanical properties have been found between various clones. This finding suggests the potential for genetically selecting higher strength clones specifically for structural lumber use. The most significant drawback to the use of hybrid poplar for lumber is its tendency to warp. Special drying is required to improve the yield of material cut. 


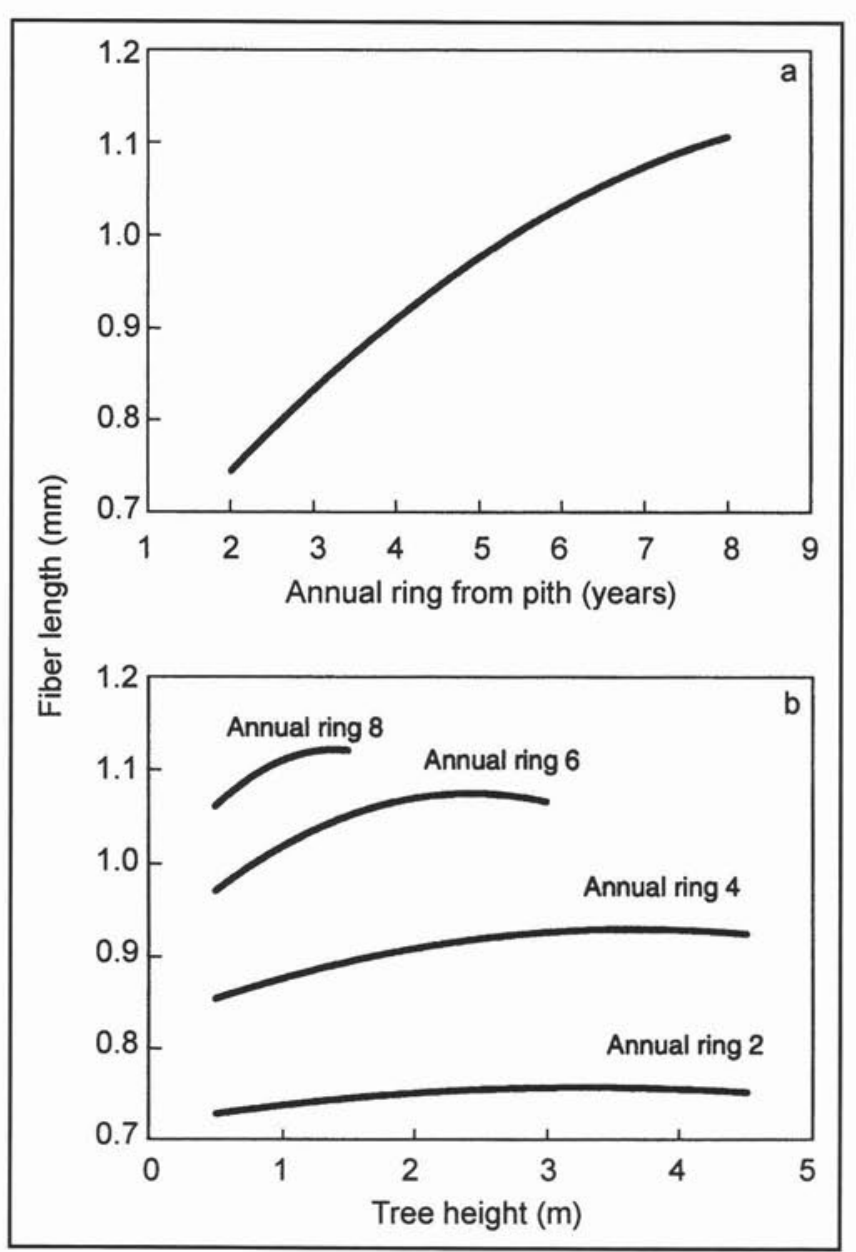

Fig. 1. (a) Average trend line for fibre length as a function of annual ring breast height; (b) trend line for fibre length as a function of stem height for various annual rings (plots created from data of Koubaa et al. 1998).

\section{Composite products}

A composite is any combination of two or more materials in any form and for any use. Composites take advantage of the beneficial characteristics of each component material and often have more useful properties than any of the constituents on their own. This broad definition includes a wide range of wood products, from composite panels (particleboard, fibreboard, waferboard, OSB, and even plywood) to composite lumber (laminated veneer lumber (LVL), PSL, laminated strand lumber (LSL), and composite wood I-beams). Depending on the type of adhesive system used in the manufacture of these products, they may be destined for "interior" (generally decorative) or "exterior" (generally structural) applications. One of the many advantages of composites is that they use wood fibre more efficiently than sawn lumber. Typical conversion efficiencies are in the range of $52 \%$ for LVL, $64 \%$ for PSL, $76 \%$ for LSL (Nelson 1997), $80 \%$ to $90 \%$ for OSB, and $85 \%$ to $95 \%$ for particleboard and fibreboard, whereas that of sawn lumber is around $40 \%$.

The manufacture of all wood-based composite products requires the initial conversion of logs into smaller elements (veneers, wafers, strands, flakes, particles, and fibres) that are subsequently reassembled and bonded into efficient structural shapes and sizes (panels and lumber-like profiles) with appropriate adhesive systems. The end result is increased product yield, improved product uniformity, and enhanced fibre value. Composites are more flexible and tolerant of wood property variation than sawn lumber, but their manufacture and properties are nevertheless influenced by wood quality. For example, the high incidence of tension wood has a negative impact on all wood machining operations involved in the manufacture of composites (veneer peeling, flaking, stranding, and sanding). Similarly, if the proportion of weak juvenile wood in the $\log$ furnish is high, the mechanical properties of the end product will be reduced.

The historical development of waferboard and OSB and their manufacturing processes was reviewed recently by Lowood (1997). The first OSB plant was built in Edson, Alberta, in 1982, and since then, OSB has become a global industry. OSB is made from long, narrow strands (flakes) of wood. It is made of several layers of these strands, with the strands in each layer aligned parallel to one another. Adjacent layers of strands are perpendicular to one another, like the cross-laminated veneers of plywood. This unique mat construction gives OSB strength and stiffness properties equivalent to plywood.

The manufacture of OSB includes the following main process steps: debarking of logs, cutting and drying of strands, blending of strands with synthetic resin and wax, mat forming, hot pressing, and finishing. Markets and applications of OSB are broad and diverse. The product can be used in virtually any structural or non-structural application where a large, thin, uniform, and dimensionally stable panel is needed. While its principal markets are in residential construction (floor, roof, and wall sheathing, siding), OSB is used in many other industries for numerous applications, including concrete forms, packaging and crating, chair seats and backs, hardwood floor core, stress skin panels, structural insulated panels, I-joist webs, pallets, shelving and display racks, and furniture frames. The continuing growth of the OSB industry will provide a major market opportunity for hybrid poplar wood from actively managed plantations. Hybrid poplar has been successfully used as a substitute for aspen in a number of structural panel products in the United States and Canada (Geimer and Crist 1980, Zhou 1990). Hybrid poplar clones have been shown to have similar properties to products made completely of aspen. However, differences in specific gravity may require some process adjustments.

From the family of structural composite lumber products, LVL and LSL deserve special mention because of the suitability of poplar wood for the manufacture of these products. Nelson (1997) provided an excellent overview of the manufacturing processes for LVL and LSL.

In a typical LVL process, rotary-peeled dried veneers coated with a waterproof structural adhesive are laid-up into a thick sandwich with parallel grain orientation between all layers of veneer. The veneer sandwich is consolidated into a solid billet under heat and pressure. LVL is manufactured to either a fixed length using a stationary or staging press or to an indefinite length in a continuous press. The solid billets exiting the press are cut into desired widths and lengths. The process facilitates the placing of lower grade veneers into the core and higher-grade veneers on the faces. Trials and tests undertaken in Canada have shown that LVL made from industrial-grade poplar 
veneer was nearly as strong and stiff as LVL made from Douglas-fir veneer. Veneer from poplar has shallower lathe checks than those that occur when dense softwoods are peeled. This reduces adhesive penetration and produces a more uniform bond. The advantages of LVL over sawn lumber include greater product uniformity, predictability of performance, broader range of available sizes, dimensional stability, and preservative or fire retardant treatability.

In the manufacture of LSL, long and slender dry strands (more than $300 \mathrm{~mm}$ long) of wood are coated with waterproof adhesive and formed into a thick mat with parallel grain orientation between strands. The mat is consolidated into a thick (up to $140 \mathrm{~mm}$ ), wide $(2.4 \mathrm{~m}$ ), and long (up to $15 \mathrm{~m}$ ) billet, which is subsequently sawn into desired structural sizes. The principal advantage of LSL is the ability to convert small-diameter (even crooked) logs. Other advantages are similar to those of LVL.

(5)

\section{Conclusions and future prospects}

From early status as a "weed tree," poplar has become an क्mportant commercial genus in North America during the past 20 years. With the introduction of waferboard, OSB and ISL, aspen utilization has dramatically increased. Indigenous and hybrid poplars, however, present their own challenges, such a s high discoloration potential, difficulty in drying, and high tiension wood content. Further research is needed for improved selection of clones to ensure that desirable physical and Enechanical qualities of poplar wood are produced for the anticqpated site location and final utilization. To date, the most promisin the pulp and paper, LSL, and structural panel industries. The hnechanical properties of structural lumber cut from hybrid poplar

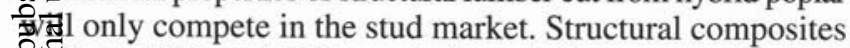
긴해 $\mathrm{h}$ as OSB and LSL made from indigenous and hybrid 월 lars can, however, be used effectively in other engineered șinictural applications.

Difire prospects for poplar utilization appear bright. With the increasing global population and industrialization, the fiemand for wood fibre is growing at an annual rate of over 60 Gillion tonnes. Much of the new supply will come from తftensively managed plantations of fast-growing trees, such . Eansformation provide new opportunities to enhance not finly growth rate and disease resistance but also some important wood properties (such as chemical composition, fibre qualny and natural durability of wood) of hybrid poplars in new Elantations (Boerjan 2000, Dinus 2000). New process techftologies in pulping and composites will continue to improve Eonversion efficiencies of the fibre resource, as well as the service performance and the ultimate recycleability of finished products.

\section{References}

Bendtsen, B.A., R.R. Maeglin and F. Deneke. 1981. Comparison of mechanical and anatomical properties of eastern cottonwood and Populus hybrid NE-237. Wood Sci. 14(1): 1-14.

Boerjan, W. 2000. Integration of new tools into long-term breeding strategies. In J.G. Isebrands and J. Richardson (compilers). USDA Forest Service North Central Research Station General Technical Report NC-215. $21^{\text {st }}$ Session of the International Poplar Commission (IPC 2000) Poplar and Willow Culture: Meeting the Needs of Society and the Environment. p. 19.
DeBell, J.D., B.L. Gartner and D.S. DeBell. 1998. Fiber length in young hybrid Populus stems grown at extremely different rates. Can. J. For. Res. 28: 603-608.

Dinus, R.J. 2000. Genetic modification of poplar wood physical and chemical properties. In J.G. Isebrands and J. Richardson (compilers). USDA Forest Service North Central Research Station General Technical Report NC-215. $21^{\text {st }}$ Session of the International Poplar Commission (IPC 2000) Poplar and Willow Culture: Meeting the Needs of Society and the Environment. p. 50.

Eckstein, D., W. Liese and A.L. Shigo. 1979. Relationship of wood structure to compartmentalization of discolored wood in hybrid poplar. Can. J. For. Res. 9: 205-210.

Forest Products Laboratory. 1999. Wood handbook - Wood as an engineering material. USDA Forest Service, Forest Products Laboratory, Madison, WI. Gen. Tech. Rep. FPL-GTR-113.

Geimer, R.L. and J.B. Crist. 1980. Structural flakeboard from shortrotation intensively cultured hybrid Populus clones. Forest Prod. J. 30(6): 42-48.

Hall, R.B, G.D. Hilton and C.A. Maynard. 1982. Construction lumber from hybrid aspen plantations in the central states. J. Forestry 80 : 291-294.

Hernandez, R.E., A. Koubaa, M. Beaudoin and Y. Fortin. 1998. Selected mechanical properties of fast-growing poplar hybrid clones. Wood Fiber Sci. 30(2): 138-147.

Holt, D.H. and W.K. Murphey. 1978. Properties of hybrid poplar juvenile wood affected by silvicultural treatments. Wood Sci. 10(4): 198-203.

Isebrands, J.G. and R.A. Parham. 1974. Tension wood anatomy of short-rotation Populus spp. before and after kraft pulping. Wood Sci. 6(3): 256-265.

Koubaa, A., R.E. Hernandez, M. Beaudoin and J. Poliquin. 1998. Interclonal, intraclonal, and within-tree variation in fiber length of poplar hybrid clones. Wood Fiber Sci. 30(1): 40-47.

Kretschmann, D.E., J.G. Isebrands, G. Stanosz, J.R. Dramm, A. Olstad, D. Cole and J. Samsel. 1999. Structural lumber properties of hybrid poplar. USDA Forest Service, Forest Products Laboratory, Madison, WI. Res. Pap. FPL-RP-573. 8 p.

Labosky, R. Jr., T.W. Bowersox and P.R Blankenhorn. 1983. Kraft pulp yields and paper properties obtained from first and second rotations of three hybrid poplar clones. Wood Fiber Sci. 15(1): 81-89.

Law, K.N., and S. Rioux. 1997. Five short-rotation poplar clones grown in Quebec: Wood and papermaking properties. Timber management toward wood quality and end product. In Proceedings of the CTIA-IUFRO International Wood Quality Workshop, August 18-22, 1997, Quebec City, Canada. VII.19-VII.28.

Lowood, J. 1997. Oriented strand board and waferboard. Engineered wood products, a guide for specifiers, designers, and users. In S. Smulski (ed.). PFS Res. Foundation. Madison, WI. pp. 123-145. Morley, P.M. and J.J. Balatinecz. 1993. Poplar utilization in Canada: past, present and future. For. Chron. 69(1): 46-52.

Nelson, S. 1997. Structural composite lumber. Engineered wood products, a guide for specifiers, designers, and users. In S. Smulski (ed.). PFS Res. Foundation. Madison, WI. pp. 147-172.

Panshin, A.J. and C. de Zeeuw. 1980. Textbook of wood technology. McGraw-Hill, Inc. New York, NY. p. 722.

Wong, A. 1987. Review of pulping and paper making properties of aspen. Report published by Canadian and Alberta Forest Service. $81 \mathrm{p}$. Youngquist, J.A. and H. Spelter. 1990. Aspen wood products utilization: impact of the Lake States composites industry. In Proceedings, Aspen Symposium 89. USDA, Forest Service, North Central Forest Experiment Station, St. Paul, MN. NC-GTR-140. pp. 91-102.

Zarges R.V. and R.D. Neuman. 1980. Kraft pulp and paper properties of Populus clones grown under short-rotation intensive culture. TAPPI. 63: 91-94.

Zhou, D. 1990. A study of oriented structural board made from hybrid poplar. Physical and mechanical properties of OSB. Holz als Roh Und Werkstoff 48(7-8): 293-296. 